\title{
PENGEMBANGAN CATU DAYA PRESISI DISPLAY DIGITAL UNTUK PRAKTIKUM FISIKA LISTRIK DINAMIS
}

\author{
Bushra Hamid $^{1}$, Frans Rizal Agustiyanto ${ }^{1}$, Yulkifli \\ ${ }^{1}$ Jurusan Fisika Fakultas Tarbiyah dan Ilmu Keguruan IAIN Batusangkar \\ Jalan Sudirman No. 137 Kubu Rajo, Lima Kaum Batusangkar 27213. \\ ${ }^{2}$ Jurusan Fisika FMIPA Universitas Negeri Padang \\ Email: bushrahamidjambak@gmail.com
}

\begin{abstract}
This study aims to generate power supply precision instrument digital display a valid and practical for students of physics 3rd semester of the school year 2014/2015. This research includes development research (research development) of the power supply circuit that has been common there are some drawbacks, namely, the output of output that does not fit, there is still AC voltage on the output value, the output voltage is unstable, so that the results of the lab basic physics 2 be not in accordance with the results of the theory. The addition of the diode bridge circuit helps perfect output voltage into DC, the capacitors in the circuit capacity was raised as a reliever ripple or ripples form to obtain a stable DC voltage value, for a voltage stabilizer is also used IC9815 surge protector. Limited trial conducted in STAIN Batusangakar to 26 students. Based on the results of data analysis has been carried out can be summarized as follows: (1) The results of the validation tool precision power supply digital display is very valid. (2) The results of trials carried out showed that the practicalities have met the criteria that can be used and implemented in a lab with practicality very practical value.
\end{abstract}

Key words: research and development, power supply, display digital

\section{PENDAHULUAN}

Fisika merupakan ilmu fundamental yang menjadi dasar bagi perkembangan ilmu pengetahuan dan teknologi. Ilmu fisika dibangun dari eksperimen yang melahirkan suatu pernyataan-pernyataan berupa konsep ataupun hukum. Salah satu cara meningkatkan pemahaman dalam pembelajaran fisika adalah melaksanakan praktikum untuk membuktikan teori yang dipelajari. Kegiatan praktikum fisika bertujuan untuk menanamkan konsep fisika yang benar, membangun sikap ilmiah, melatih keterampilan-keterampilan berproses dalam kerja ilmiah.

Praktikum materi listrik dinamis memerlukan sumber tegangan seperti baterai, aki, power supply atau catu daya. Baterai adalah sumber tegangan dengan arus searah (DC) dan bahan habis pakai jika digunakan secara terus menerus maka tegangannya akan berkurang. Hal ini tidak efektif dalam praktikum. Sumber tegangan dari PLN memiliki arus bolak balik (AC) dengan tegangan 220 volt. Karena itu dibutuhkan sebuah catu daya 
yang merupakan peralatan penyedia tegangan atau sumber daya dengan prinsip mengubah tegangan listrik yang tersedia dari jaringan distribusi transmisi listrik ke level yang diinginkan sehingga berimplikasi pada pengubahan daya listrik dalam sistem pengubahan daya.

Catu daya yang ada di Laboratorium Fisika STAIN Batusangkar dengan produk dari Pudak Scientific AC dan DC Kal. 60/5A Model 10015e memiliki tegangan $0,2,4,6,8,10,12$ volt. Jika diukur dengan menggunakan multimeter pada saat selector switch diletakkan pada posisi 2 volt, ternyata tegangan yang ditemukan tidak sesuai dengan yang ditunjukkan pada selector switch serta tidak memiliki tegangan bernilai ganjil sehingga dalam praktikum yang memiliki nilai tegangan ganjil tidak bisa dilakukan. Catu daya pudak scientific ini memiliki tegangan dengan arus $\mathrm{AC}$ dan DC. Tegangan dengan arus DC memiliki hasil keluaran membentuk gelombang, seharusnya hanya berupa garis lurus seperti baterai

Berdasarkan permasalahan tersebut, peneliti mengembangkan alat catu daya yang ada di Laboratorium STAIN Batusangkar berupa alat catu daya dengan tegangan yang dapat divariasikan serta memiliki tampilan digital untuk melihat output tegangan pada catu daya serta memiliki tegangan dengan arus DC yang mendekati baterai, karena baterai memiliki arus searah (DC) yang bagus.

\section{METODE PENELITIAN}

Penelitian ini digolongkan pada penelitian pengembangan (research development). Dalam hal ini dikembangkan alat catu daya presisi display digital untuk praktikum materi listrik dinamis yang difokuskan pada hukum kirchoff 1. Praktikum dilaksanakan di Laboratorium Fisika STAIN Batusangkar terhadap mahasiswa semester 3.

Prosedur penelitian yang dilakukan dimulai pada tahap pendefenisian (define) yang dimulai dari Analisis Alat Praktikum, Analisis Literatur Modul Penuntun Praktikum, Analisis Praktikan danAnalisis Kosep.

Adapun langkah-langkah yang dilalui dalam tahap perancangan (design) ini adalah: tahap perancangan alat catu daya presisi display digital dengan langkah-langkah yaitu: Analisa rangkaian catu daya umum pada rangkaian, menggambarkan skema rangkaian catu daya presisi display digital, yaitunya: catu daya dan voltmeter digital, membuat layout dan tata letak dari skema rangkaian catu daya dan voltmeter digital pada kertas, memindahkan layout ke papan PCB, melakukan pemasangan komponen, mendesain box dan pemberian box untuk rangkaian catu daya, melakukan tahap uji coba dengan oscilloscope, melakukan uji coba dengan sebuah rangkaian sederhana tentang listrik. Tahap uji coba alat catu daya presisi display digital dilakukan dalam pelaksanaan praktikum. Modul penuntun praktikum digunakan sebagai alat bantu dalam pelaksanaan praktikum. Perancangan modul dilakukan dengan membuat cover, kata pengantar, daftar isi, format penulisan laporan praktikum, petunjuk pelaksanaan praktikum, tujuan percobaan, alat dan bahan, landasan teori, langkah kerja, data pengamatan, evaluasi akhir dan daftar pustaka. Sebelum diuji cobakan modul divalidasi oleh pakar/ahli.

Tahap pengembangan (develop) meliputi validasi dan angket. Sebelum alat diuji coba dalam sebuah rangkaian, alat dikalibrasi. Kalibrasi alat dilakukan untuk menyesuaikan antara alat yang dibuat 
dengan alat atau produk standar. Setelah kalibrasi alat dilakukan pengujian terhadap produk. Pengujian produk dilakukan untuk membuktikan bahwa parameter tersebut memenuhi penyaratan untuk digunakan. Validasi alat catu daya presisi display digital ini digunakan sebagai uji kelayakan dan peningkatan mutu atas produk yang dihasilkan. Selain alat divalidasi oleh pakar/ahli, alat diuji coba dan dilakukan pengukuran sesuai dengan alat atau produk standar. Uji coba alat yang dilakukan yaitu: ketelitian (accuracy), resolusi, kecermatan (precision), sensitivitas (sensitifity), dan stabilitas alat. Sedangkan validasi modul penuntun praktikum dapat dilihat pada Tabel 1.

Tabel 1 Aspek Penilai Produk

\begin{tabular}{clcc}
\hline Tabel & \multicolumn{3}{c}{ Validasi Modul Penuntun Praktikum } \\
\hline No & \multicolumn{1}{c}{ Aspek } & Metode Pengumpulan Data & Instrumen \\
\hline 1 & Kelayakan isi / didaktik & & \\
2 & Kelayakan konstruksi & Validator & Lembar \\
3 & Komponen bahasa & & validasi \\
4 & Teknis & & \\
\hline
\end{tabular}

Tahap uji coba praktikalitas semester 3 di Laboratorium Fisika IAIN terbatas pada praktikum fisika materi Batusangkar. Adapun komponen yang listrik dinamis tentang hukum kirchoff 1 diteliti dapat dilihat pada Tabel 2. yang dilaksanakan oleh mahasiswa fisika

Tabel 2 Praktikalisasi Alat Catu Daya Presisi Display Digital

\begin{tabular}{rlrl}
\hline No & \multicolumn{1}{c}{ Aspek } & $\begin{array}{c}\text { Metode } \\
\text { Pengumpulan } \\
\text { Data }\end{array}$ & Instrumen \\
\hline 1 & $\begin{array}{l}\text { Kemudahan dalam penggunaan alat catu daya } \\
\text { presisi digital digital }\end{array}$ & Angket & $\begin{array}{l}\text { Lembar angket } \\
\text { praktikalisasi alat } \\
\text { Angket respon }\end{array}$ \\
2 & $\begin{array}{l}\text { Respon praktikan dalam pelaksanaan } \\
\text { praktikum dengan menggunakan alat catu } \\
\text { daya presisi display digital berbantuan modul } \\
\text { penuntun praktikum }\end{array}$ & Angket & \\
\hline
\end{tabular}

\section{HASIL DAN PEMBAHASAN}

\section{Hasil Tahap Pendefinisian (define)}

Tahap pendefenisian terdiri dari analisis praktikum, literatur modul penuntun praktium, praktikan dan konsep. Pada analisis alat praktikum dilihat dari keterbatasan catu daya yang ada di
Laboratorium Fisika STAIN Batusangkar dari produk Pudak Scientific AC dan DC Kal. 60/5A Model 10015e yang hanya memiliki tegangan untuk bilangan genap saja serta menghasilkan tegangan yang tidak sesuai dengan yang tertera pada selektor switch alat. Berdasarkan uji coba 
Hamid, H., Agustiyanto, F. R., \& Yulkifli. 2016. Pengembangan Catu Daya Presisi Display Digital untuk Praktikum Fisika Listrik Dinamis. Journal of Sainstek 8(2): 193-202

yang dilakukan pada catu daya produk oscilloscope menghasilkan tampilan pudak tersebut dengan menggunakan seperti Gambar 1.

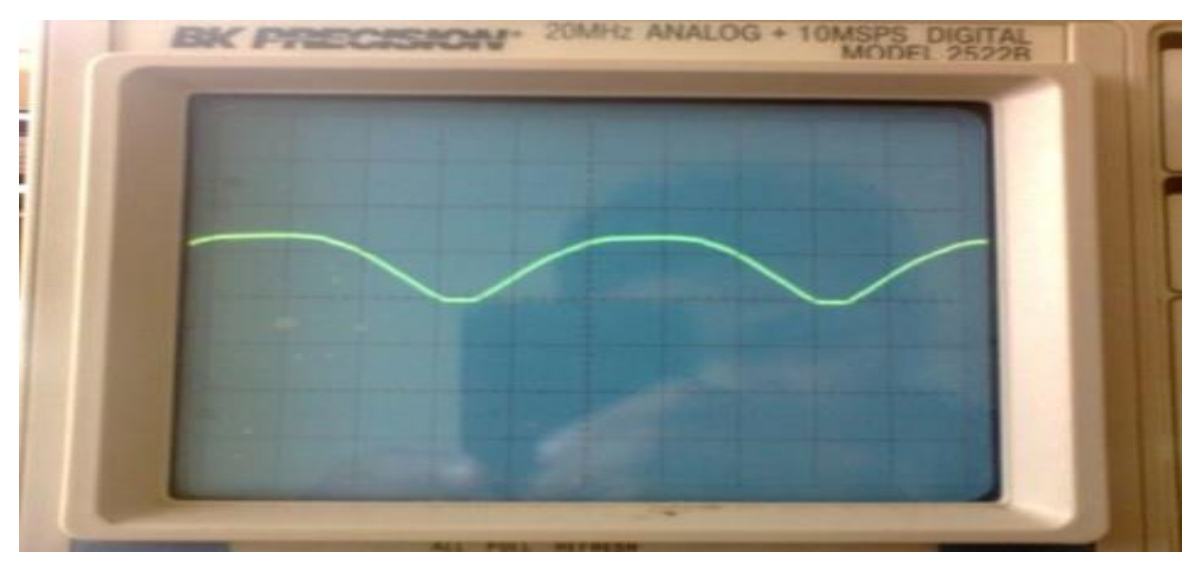

Gambar 1 Bentuk Tegangan Keluaran Catu Daya Produk Pudak Scientific

Pada Gambar 1 terlihat bahwa hasil tegangan keluaran dengan arus searah (DC) pada catu daya produk pudak scientific tersebut memiliki bentuk gelombang dengan riak yang cukup besar.
Hasil tegangan keluaran baterai dengan menggunakan oscilloscope dapat dilihat pada Gambar 2 membentuk garis lurus. ini menunjukkan bahwa baterai memiliki tegangan dengan arus searah yang bagus.

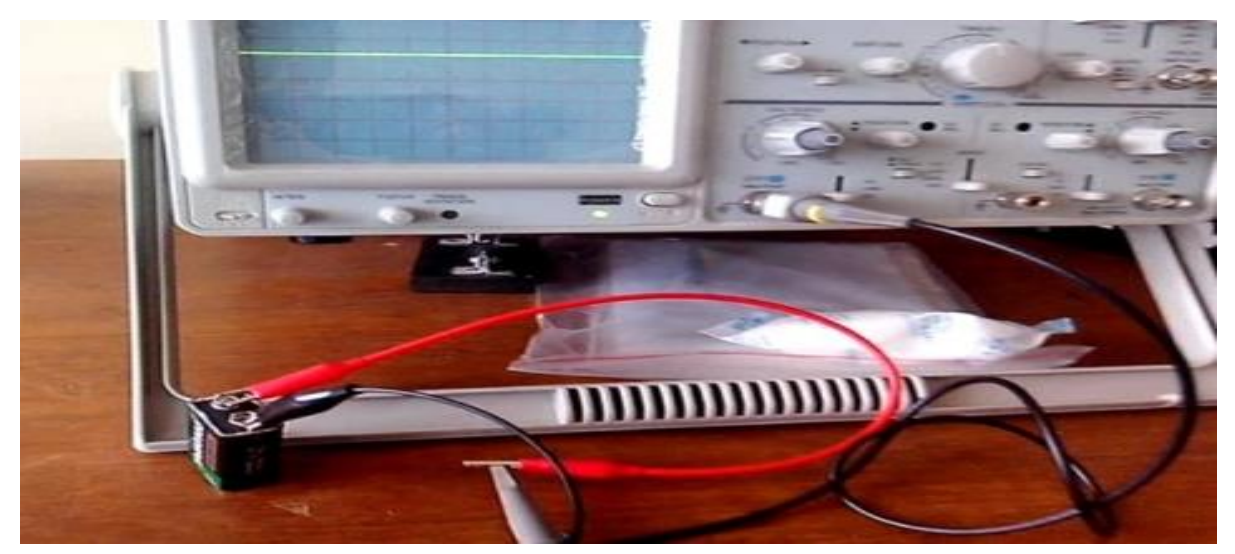

Gambar 2 HasilTegangan Keluaran Baterai 9 Volt

Modul penuntun praktikum praktikum fisika materi listrik dinamis digunakan untuk membantu pelaksanaan tentang hukum kirchoff 1. Pada analisis 
Praktikan dapat dilihat berdasarkan hasil laporan praktikum dari salah seorang mahasiswa fisika yang melaksanakan praktikum fisika dasar materi hukum kirchoff 1 mahasiswa menganggap bahwa hasil tegangan keluaran catu daya dari produk pudak scientific memiiki nilai sesuai dengan yang tertera pada penunjuk selektor switch. Sebelum diukur terlebih dahulu. Pelaksanaan praktikum dengan benar dalam membuktikan konsep atau hukum dapat meningkatkan pemahaman.

\section{Hasil Tahap Perancangan (design)}

Alat catu daya presisi display digital dirancang agar pelaksanaan praktikum dapat terlaksana dengan efektif dan efisien. Alat didesain dengan bentuk yang sederhana dan menarik agar alat mudah untuk digunakan. Desain dari alat catu daya presisi display digital ini seperti pada Gambar 3.

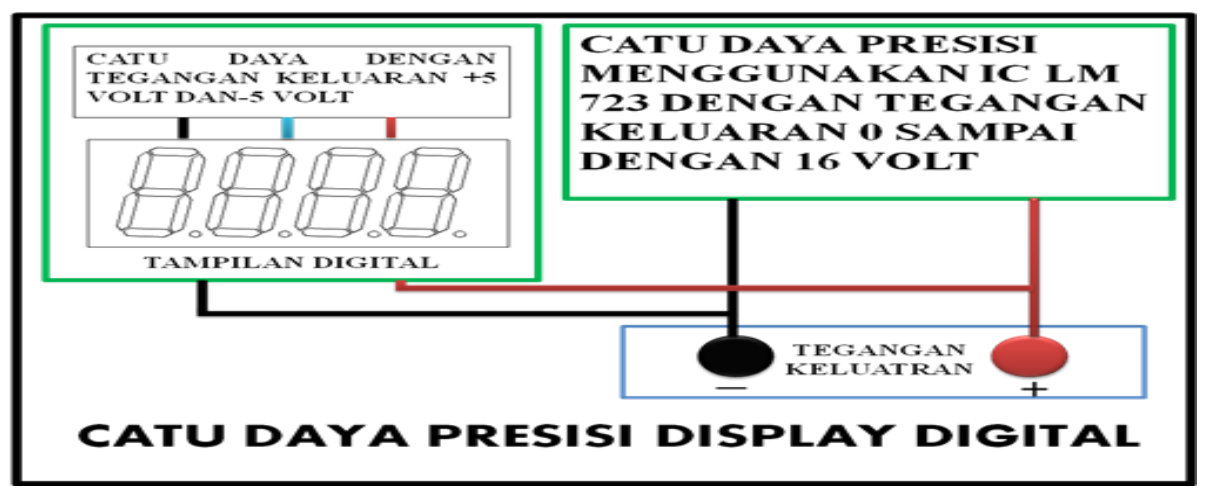

Gambar 3. Blok Catu Daya Presisi Display Digital

Berdasarkan Gambar 3 catu daya presisi display digital terdiri dari dua bagian yaitu catu daya presisi dan pembaca besaran tegangan keluaran dengan tampilan digital. Kedua bagian ini digabung menjadi suatu kesatuan yang dinamakan dengan catu daya presisi display digital. Pada bagian catu daya presisi memiliki hasil tegangan keluaran yang stabil. Hasil keluaran catu daya presisi akan dibaca oleh rangkaian voltmeter digital. Voltmeter digital ini memiliki catu daya khusus dengan tegangan input +5 volt dan -5 volt. Alat catu daya presisi display digital ini merupakan penggabungan dua rangkaian yaitu rangkaian catu daya dan rangkaian voltmeter digital. Skema rangkaian catu daya dapat dilihat pad a Gambar 4 dan skema rangkaian voltmeter digital pada Gambar 5.

\section{Hasil Tahap Pengembangan (develop)}

Kalibrasi alat catu daya presisi display digital dapat dilakukan dengan memutar trimpot (resistor variabel) yang ada pada rangkaian bagian pembaca nilai tegangan (voltmeter digital) dengan menggunakan obeng minus (-). Tampilan pembaca tegangan pada catu daya dibandingkan dengan multimeter digital sanwa CD800a dapat dilihat pada Tabel 4 dan Gambar 6. 


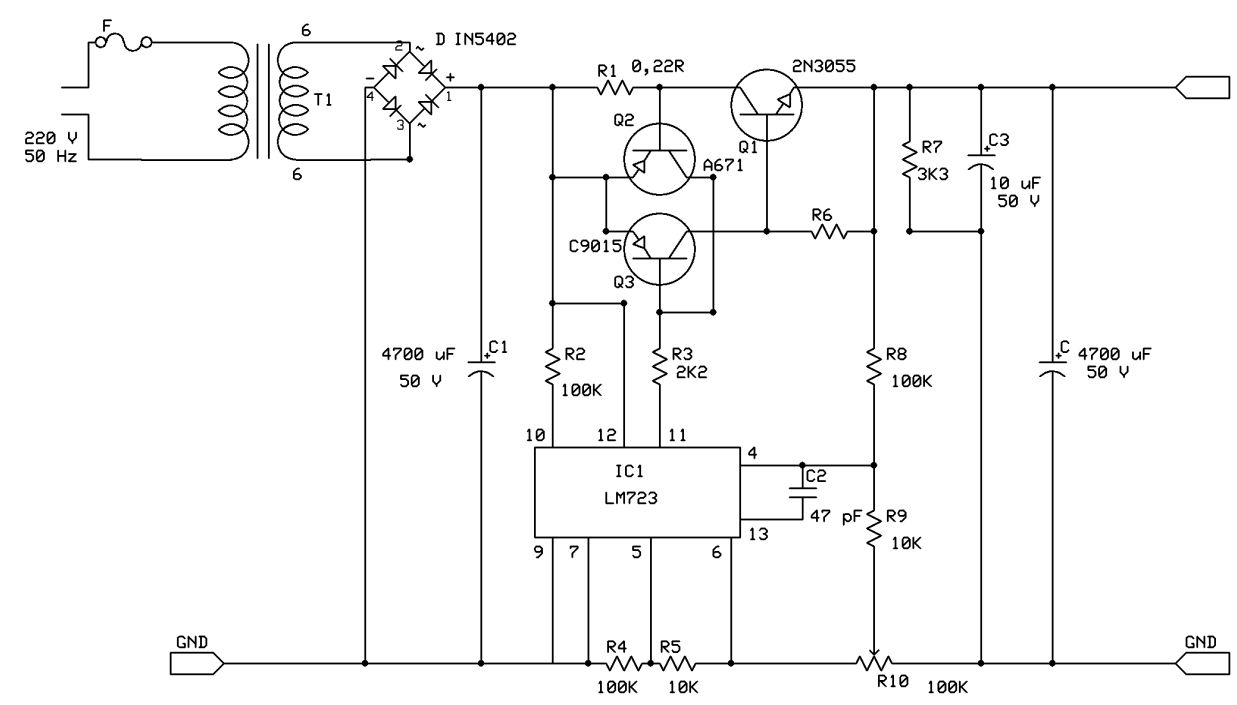

Gambar 4. Skema Rangkaian Catu Daya

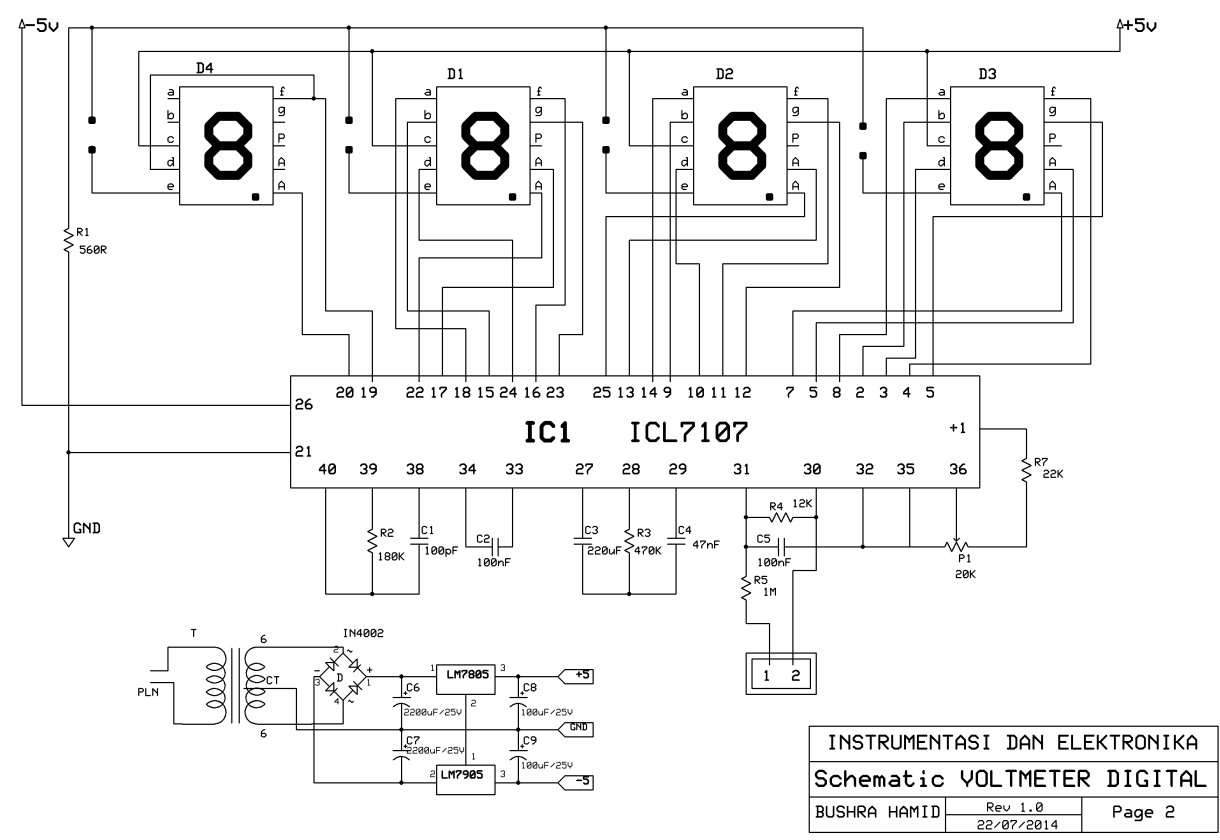

Gambar 5 Skema Rangkaian Voltmeter Digital 


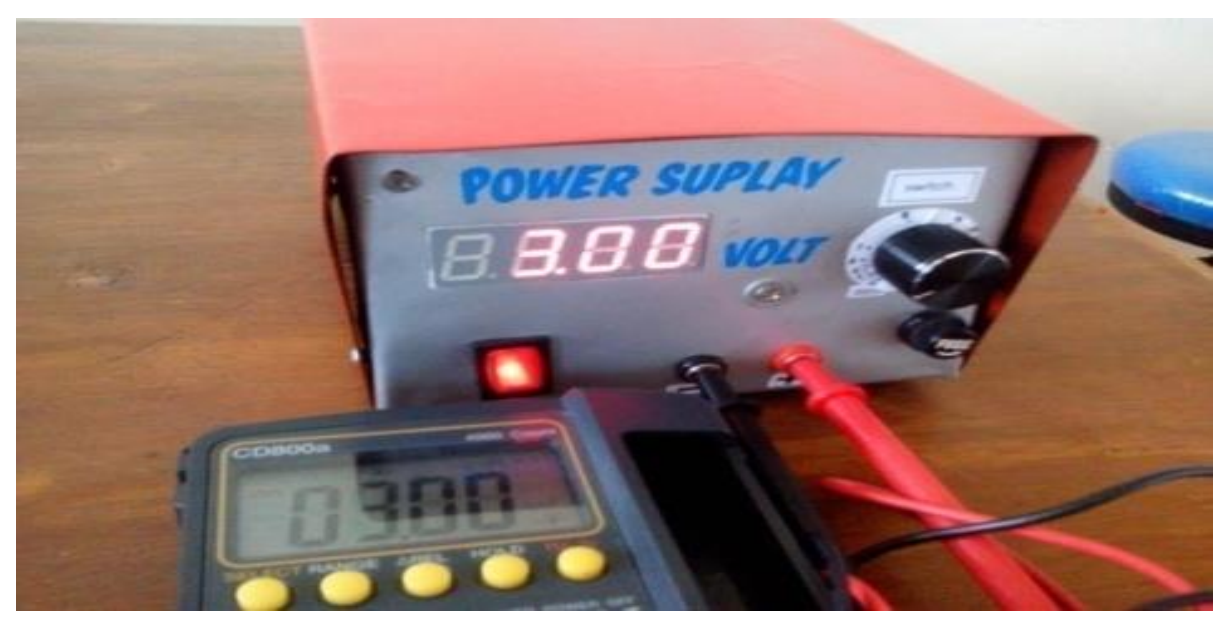

Gambar 6 Hasil Tegangan Alat Ukur Standar dengan Alat Ukur yang Dibuat

Tabel 4. Hasil Hubungan Alat Ukur Standar dengan Alat Ukur yang Dibuat

\begin{tabular}{cclll}
\hline No & $\mathrm{V}_{\text {AUS }}$ & $\mathrm{V}_{\mathrm{UAD}}$ & $\Delta \mathrm{V}=\mathrm{V}_{\mathrm{AUS}}-\mathrm{V}_{\mathrm{AUD}}$ & $\%$ Kesalahan \\
\hline 1 & 1,00 & 1,00 & 0,00 & 0 \\
2 & 2,00 & 2,00 & 0,00 & 0 \\
3 & 3,00 & 3,00 & 0,00 & 0 \\
4 & 4,00 & 4,00 & 0,00 & 0 \\
5 & 5,00 & 5,00 & 0,00 & 0 \\
6 & 6,00 & 6,00 & 0,00 & 0 \\
7 & 7,00 & 7,01 & 0,01 & 0,14 \\
8 & 8,00 & 8,01 & 0,01 & 0,13 \\
9 & 9,00 & 9,01 & 0,01 & 0,11 \\
10 & 10,00 & 10,01 & 0,01 & 0,1 \\
11 & 11,00 & 11,01 & 0,01 & 0,09 \\
12 & 12,00 & 12,01 & 0,01 & 0,08 \\
13 & 13,00 & 13,01 & 0,01 & 0,08 \\
14 & 14,00 & 14,01 & 0,01 & 0,07 \\
15 & 15,00 & 15,01 & 0,01 & 0,07 \\
16 & 16,00 & 16,01 & 0,01 & 0,06 \\
\hline \multicolumn{7}{l}{ Rata-rata } & & 0,00625 & 0,058125 \\
\hline
\end{tabular}

Untuk lebih jelasnya data dibuat dalam bentuk grafik seperti pada Gambar 7. 


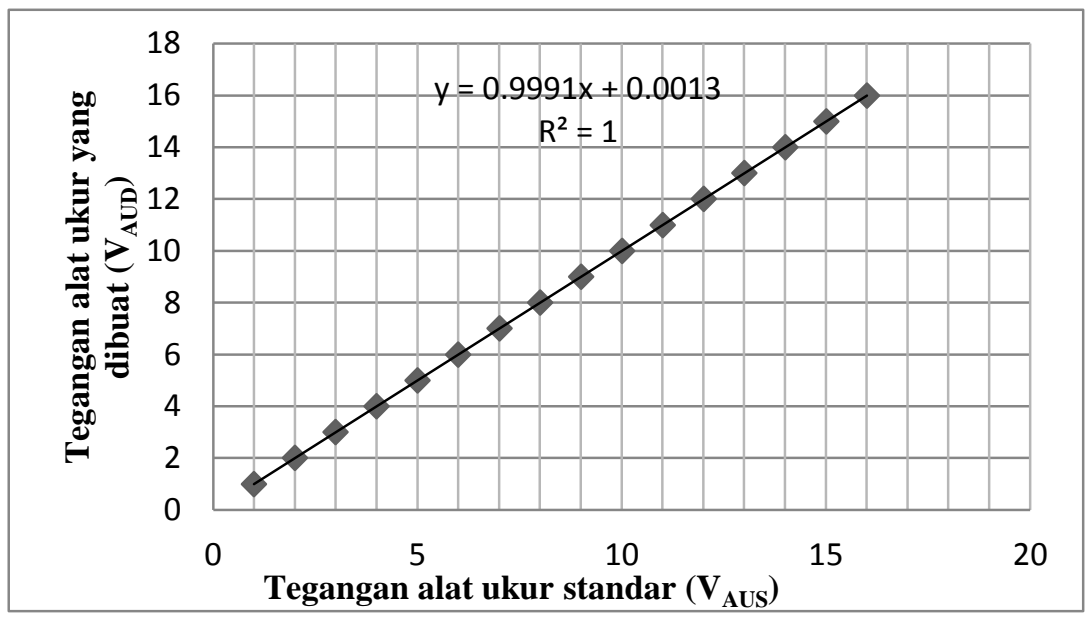

Gambar 7. Grafik Hubungan antara Alat Ukur Standar Dengan Alat Ukur yang Dibuat

Alat catu daya presisi display digital juga diuji coba dengan menggunakan oscilloscope atten model AT $7328 \quad 20 \mathrm{MHz}$ dengan seri
ASP1311003798 untuk melihat tegangan dan arus yang hasilkan oleh alat catu daya presisi display digital. Hasil uji coba alat dapat dilihat pada Gambar 8.

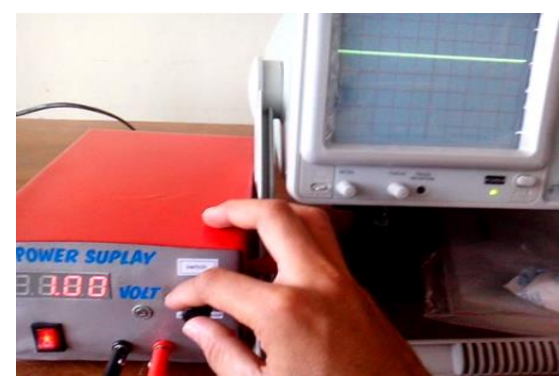

(a) Untuk Tegangan 1 Volt

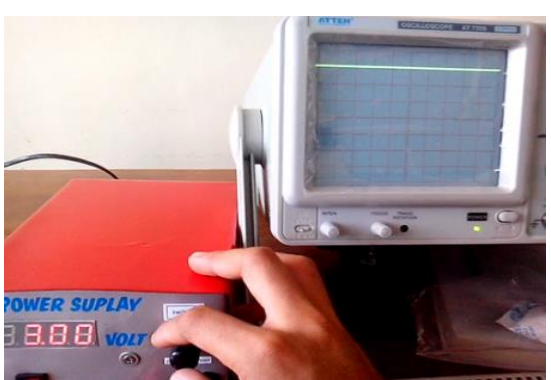

(b) Untuk Tegangan 3 Volt

Gambar 8 Hasil Keluaran Tegangan Catu Daya dengan Menggunakan Oscilloscope

Hasil yang ditampilkan oscilloscope menunjukkan tegangan keluaran catu daya presisi display digital membentuk sebuah garis lurus. Hasil tersebut menunjukkan bahwa tegangan yang dihasilkan catu daya presisi display digital memiliki arus searah (DC) yang bagus.
Hasil pengukuran catu daya presisi display digital dapat dilihat sebagai berikut: 1). Ketelitian (Accuracy), pada Tabel 4 alat catu daya presisi display digital terdapat perbedaan atau kesalahan (error) terhadap alat ukur standar. Nilai selisih paling besar adalah 0,01 volt. Alat catu daya presisi display digital bisa dikatakan akurat.2). Resolusi, berdasarkan 
hasil tampilan digital pada Tabel 4, salah satu tegangan yang dihasilkan alat catu daya presisi display digital adalah 7,01 volt. Tegangan bisa divariasikan dalam bentuk bilangan desimal dengan nilai skala terkecil (NST) sebesar 0,01 volt. Hasil data menunjukkan bahwa alat catu daya presisi display digital memiliki resolusi 0,01 volt. 3). Kecermatan (Precision), alat catu daya bisa dikatakan presisi jika alat menunjukkan nilai yang sama untuk pengukuran berulang. Data dapat dilihat pada Tabel 5 dengan tegangan keluaran alat catu daya presisi display digital menunjukkan nilai yang sama dengan melakukan 10 kali pengukuran berulang. Data tersebut menunjukkan bahwa alat catu daya presisi display digital memiliki presisi yang tinggi. Untuk lebih jelasnya data dapat dilihat pada grafik seperti pada Gambar 9.
4). Sensitivitas (Sensitifitas), Berdasarkan Gambar 6 grafik hubungan antara alat ukur standar dengan alat ukur yang dibuat diperoleh persamaan $\mathrm{Y}=0,999 \mathrm{X}-0,001$. $\mathrm{Y}$ adalah tegangan menggunakan alat ukur yang dibuat dan $\mathrm{X}$ adalah tegangan menggunakan alat ukur standar. Sensitivitas alat sebesar 0,999. 5). Stabilitas, berhubungan dengan hasil pembacaan nilai tegangan yang tidak berubah-ubah selama pengukuran. Pengukuran tegangan dilakukan selama 50 menit untuk tegangan 2 volt dan 50 menit untuk tegangan 4 volt. Data dapat dilihat pada Tabel 6 yang terlihat bahwa tegangan catu daya presisi display digital tidak berubah selama 50 menit. berdasarkan data tersebut catu daya presisi display digital memiliki stabilitas yang baik.

Tabel 5 Pengukuran Berulang Tegangan Keluaran Catu Daya

\begin{tabular}{ccccccccccc}
\hline Tegangan & \multicolumn{10}{c}{ Pengukuran Berulang } \\
\cline { 2 - 11 } (Volt) & 1 & 2 & 3 & 4 & 5 & 6 & 7 & 8 & 9 & 10 \\
\hline 2,00 & 2,00 & 2,00 & 2,00 & 2,00 & 2,00 & 2,00 & 2,00 & 2,00 & 2,00 & 2,00 \\
4,00 & 4,00 & 4,00 & 4,00 & 4,00 & 4,00 & 4,00 & 4,00 & 4,00 & 4,00 & 4,00 \\
\hline
\end{tabular}

Tabel 6. Pengukuran Tegangan terhadap Waktu

\begin{tabular}{ccccccccccc}
\hline $\begin{array}{c}\text { Tegangan } \\
\text { (Volt) }\end{array}$ & $\mathbf{5}^{\prime}$ & $\mathbf{1 0}^{\prime}$ & $\mathbf{1 5}^{\prime}$ & $\mathbf{2 0}^{\prime}$ & $\mathbf{2 5}^{\prime}$ & $\mathbf{3 0}^{\prime}$ & $\mathbf{3 5}^{\prime}$ & $\mathbf{4 0}^{\prime}$ & $\mathbf{4 5}^{\prime}$ & $\mathbf{5 0}^{\prime}$ \\
\hline 2,00 & 2,00 & 2,00 & 2,00 & 2,00 & 2,00 & 2,00 & 2,00 & 2,00 & 2,00 & 2,00 \\
4,00 & 4,00 & 4,00 & 4,00 & 4,00 & 4,00 & 4,00 & 4,00 & 4,00 & 4,00 & 4,00 \\
\hline
\end{tabular}

Hasil Validasi terhadap alat catu daya presisi display digital yang dikembangkan adalah $89 \%$ atau sangat valid, validasi petunjuk penggunaan alat $83 \%$ atau sangat valid, modul penuntun praktikum $82 \%$ atau sangat valid, validasi angket praktikalisasi alat $79 \%$ atau valid dan angket respon praktikan $75 \%$ atau valid. Hasil Praktikalisasi dilakukan pada mahasiswa fisika semester 3 yang berjumlah 26 orang di Laboratorium Fisika STAIN Batusangkar. Hasil angket 
praktikalisasi alat $85 \%$ atau sangat praktis dan hasil angket respon praktikan $81 \%$ atau sangat praktis. Secara umum hasil praktikalisasi sangat praktis dengan ratarata $83 \%$.

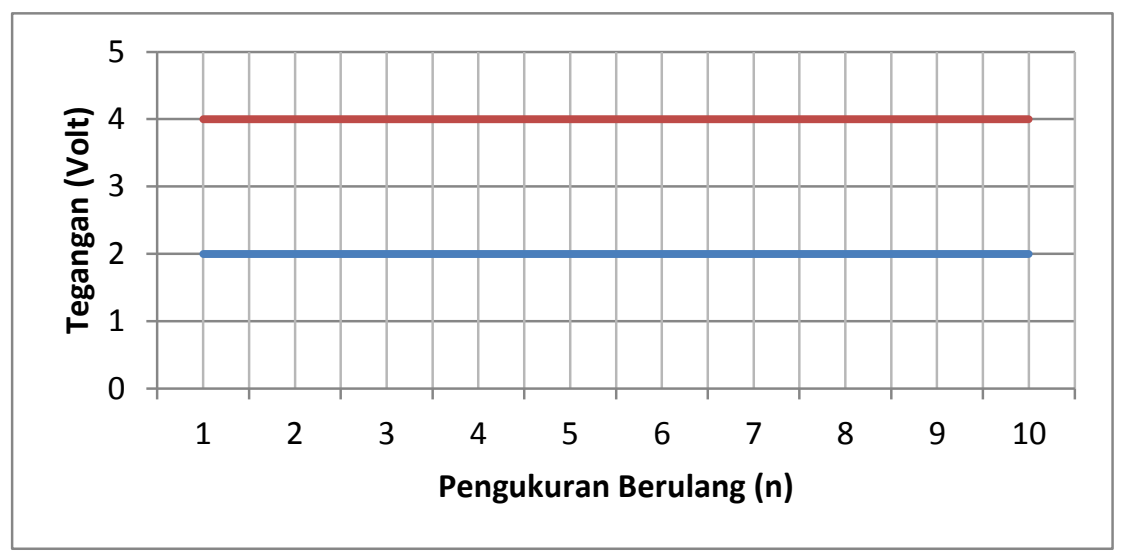

Gambar 9. Grafik Pengukuran Berulang terhadap Tegangan Keluaran Catu Daya

\section{KESIMPULAN}

Alat catu daya presisi display digital memiliki tampilan dengan menggunakan seven-segmen sebagai hasil keluaran tegangan. Tegangan pada catu daya presisi display digital dapat divariasikan dengan memutar switch yang ada pada catu daya. Alat catu daya divalidasi oleh pakar fisika. Praktikalisasi diberikan kepada mahasiswa fisika semester 3 .

\section{DAFTAR KEPUSTAKAAN}

Arifianto, Deni. 2011. Kumpulan rangkaian Elektronika sederhana. Jakarta: PT.Kawan Pustaka.

Depari, Gandi. 2003. Keterampilan elektronika untuk pemula. Bandung: M2S Bandung.

Elektonic pojects circuit (http://www.eleccircuit.com/tag/2n 3055-transisitor/feed diakses pada tanggal 3 maret 2014).
Malvino, Albert Paul. 1985. Prinsipprinsip elektronika, Terj. M.Barmawi dan M.O. Tjia, Judul asli "Electronic principles 3rd edition”, Jakarta: Erlangga.

Riduwan. 2007. Belajar Mudah Penelitian. Jakarta: Alfabeta.

Sobirin, Ma'as, dkk. 2013. Pengembangan Lembar Kerja Siswa Bahasa inggris Bermuatan Nilai Pendidikan Karakter Kelas V Madrasah Ibtidaiyah Semarang. Universitas Negeri Semarang. (journal of Educational. http://journal .unnes.ac.id/sju/index.hph/jpe diakses tanggal 4 november 2014). Sugiyono. 2007. Metode Penelitian Pendidikan. Bandung: Alfabeta.

Trianto. 2009. Mendesain Model Pembelajaran Inovatif-Progresif: Konsep, Landasan, dan Implementasi Pada KTSP. Jakarta: Kencana. 